\title{
New Elements in the Tax Control in Hungary
}

\author{
László Pardavi* \\ * Dr. László Pardavi PhD, Associate Professor for Financial Law, Department of Administrative and \\ Financial Law, Faculty of Law, Széchenyi István University. (e-mail: pardavi-laszlo@t-online.hu)
}

\begin{abstract}
The system-wide regulation of taxes in Hungary clearly represents the lawmakers' constant strive for making the law up-to-date. Currently, Hungary has approximately 60 types of taxes or fees, and it is a huge challenge to fulfill tax policy aims in order to make the regulation suitable for all of them. In recent years, tax authorities - given by the possibilities of the regulation - have introduced numerous, specific tax control methods, while some of these provide interesting legal solutions, but more importantly several of them have significant impact on taxpayers. The study introduces applicational experiences with some of these.
\end{abstract}

Keywords: administrative control; tax control; on-line cash register; road-trade control system; value added tax; tax rate

\section{Online Cash Registers}

Pursuant to paragraphs 159 and 166 of Act CXXVII of 2007 on Value Added Tax (hereinafter VAT Act), taxpayers are obliged to give invoice or bill in case of selling of goods or provision of services. The latter one can only be applied if, based on law, the taxpayer is not obliged to give invoice. Based on the tax authority's controlling experiences, several defaults and misuses have happened in connection with the obligation of providing invoice and bill, hence, the investigation of connected regulation has become actual.

In government decision No. 1457/2012 (X. 19.) on tasks connected to measures increasing the balance of the budget, the government decided to investigate and prepare the connection of cash registers with the national tax authority. As its result, the parliament modified the VAT Act with Act CCVIII of 2012 on certain acts' connection to the preparation of the central financial act as well as its modification with other purposes, supplementing the VAT Act with a new paragraph - 178. (1a) - making it possible to create such a law which could prescribe that the operation of cash registers serving to issue invoice should be controlled by the state tax authority through its communication device and system. Government resolution No. 1059/2013 (II. 13.) on the introduction of cash registers that feature an online data connection with the National Tax and Customs Administration Office regulated the introduction of new cash registers. The obligatory starting day of their application was May 1,2013, while the sanction free use of traditional cash registers' was allowed until June 30, 2013. 
However, due to the emerging technical difficulties, the deadline was extended ${ }^{1}$ until September 1, 2013. Requirements connected to new cash registers were laid down in the Decree of the Minister of National Economy 48/2013 (XI. 15.). The peculiarity of cash registers and the system lies in the fact that certain taxpayers (such as retailers, pharmacies, caterers, travel agencies, repairmen, etc.) can only fulfill their invoicing obligation using online cash registers.

Online cash registers basically consist of two main parts. One of them looks like and functions as a traditional cash register, the other one is a so called fiscal control unit (furthermore referred to as FCU). Simultaneously with the printing of invoices, FCU records the data on them in an electronic diary and those data can be directly controlled and accessed by the tax authority anytime with the assistance of online connection without the permission and knowledge of the taxpayers. At least one time a day, FCU shuts the electronic diary, provides it with electronic signature and through online connection, sends it to a server being under the commission of the National Tax and Customs Administration Office. Based on Act XCII of 2003 on the Order of Taxation, this information can be used by the tax authority for the controlling of tax payers' taxation obligations. Through a communication device and system (online system), the tax authority also has the technical and legal possibility to regularly, or even occasionally control the operation of cash registers serving the compliance with issuing invoice. For instance, the tax authority is obliged to supervise the fulfilling of invoicing obligation via an inspector doing mystery shopping in an exact time announced beforehand, without the inspector revealing him/herself after the transaction.

Of course, the database created during the operation of the system is or will be able to analyze and compare the tax payers' activity in certain periods. Such as the reasons someone has had significantly less income in the same period of the previous year compared to the period after the introduction of the cash registers.

Whether the results of the introduction can already be seen is a further question to ask. It seems that the answer is yes. According to the Minister for National Economy's statement ${ }^{2}$ given on the $7^{\text {th }}$ of March 2015, more than 180, 000 retailers used cash registers in 2014, and companies operating in the trade industry declared 250 billion HUF more VAT than the year before. Due to the success of online cash registers, this year the government would make their usage obligatory in the service sector as well. For instance, from 1 January 2017 taxi drivers, car repair shops and parts traders, plastic surgeons, dance clubs, discos, laundries, gyms are also obliged to supply the sales data to the NAV via the Automated Surveillance Unit (ASU).

Besides the on-line cash registers, currently three linked systems help to discover VAT fraud in Hungary. By detecting money's route through bank transfer investigation, the goods' movement with the help of EPRTCS system and with itemized VAT declaration invoices these can be investigated. 


\section{The Electronic Public Road Trade Control System (EPRTCS) ${ }^{3}$}

In harmony with the VAT directive, Hungary does not levy sales tax in case of goods' sale within the Community and outside the Community. ${ }^{4}$ However, it ensures the deduction and reclaim of VAT $^{5}$ in these cases, too. The Schengen Agreement (14 June 1985) abolished inner boarders between member states, which, in case of community sale and purchase, made it almost uncontrollable for the Hungarian tax authority to control whether goods really enter the territory of the country or they leave it, or even whether it is a real business or not.

In case of community purchase of goods and goods import it is a further question whether they announce goods' entrance at the tax authority (customs authority) and coincidentally they fulfill their VAT declaration and payment obligation or not; or they sell or circulate goods without taxation, causing damages to the budget. The lower domestic sales price without the higher VAT creates a significant competitive disadvantage for fair tax payers.

The phenomenon's legal background can be found in the norms of the European Union. Article 168(a) of the VAT Directive 2006/112 makes it possible that if goods and services are used for the purposes of the taxed transactions of a taxable person, the taxable person shall be entitled, in the Member State he carries out these transactions, to deduct the following from the VAT which he is liable to pay: the VAT due or paid in that Member State in respect of the supplies of goods or services to him, carried out or to be carried out by another taxable person. This regulation not requiring other certificate but an invoice provided a huge opportunity for tax dodgers, making it possible to deduct or even reclaim the extremely high $27 \%$ of VAT after fictive businesses.

At first, the Hungarian state saw the solution to this problem in the increase of investigations and the coherent regulation of investigation practice with directives. In 2012, however, this controlling practice of the tax authority and court rulings accepting this method mostly proved to be contrary to the law of the European Union according to the Court of Justice of the European Union. Rulings made in the combined cases of C-80/11 and C-142/11 on June 21, 2012 (ruling of combined cases of Mahageben and David) and case No. C-324/11 (Tóth case) on 6 September 2012 pointed out that the practice of case law and the tax authority need to be investigated as it is not the tax payer but the tax office who on the basis of objective evidence, has to prove that the taxable concerned knew, or ought to have known, that the transaction taken as a legal basis for the deduction was connected with fraud committed by the issuer of the invoice or by another trader acting earlier in the chain of supply.

Custom borders between member states, the lack of investigation that used to be applied there and the two conclusions described above greatly obstruct the customs authority's successful and effective procedure; hence, the Hungarian state tried to move forward with the formation of a new control system called EPRTCS in order to formalize the informal economy and control VAT deductions and reclaims. The system was launched on 1 January 2015.

The system aims at enabling the tax authority to follow products and goods' route, hence ensuring that common charges connected to them are properly paid and/or that 
VAT is legally deducted. Furthermore, the system is also an adequate tool for observing food-safety rules.

In Hungary, public road carriers shall pay fee for the usage of motorways, dual carriageways and main roads. Cameras of the control system (HU-GO) formed by Act LXVII of 2013 on the mileage-dependent toll payable for the use of motorways, dual carriageways and main roads are adequate for the controlling of goods' transportation as well, hence, only the already given technical background had to be connected with the adequate legal tool.

According to the regulation: product sale, product purchase and other product movement carried out by vehicles subject to road toll payment and done by public road transportation can exclusively be completed by tax payers having EPRTCS number. Furthermore, EPRTCS number also needs to be claimed if so called risky goods are transported by vehicles not subject to road toll payment. In order to get EPRTCS number, the tax payer has to make an announcement on the electronic site of EPRTCS. In doing so, the consignor's data (name, tax ID), the consignee's data (name, tax ID), as well as other data determined in the ministerial regulation issued for the implementation of the act has to be announced at the National Tax and Customs Authority (hereinafter "NTCA" or "tax authority"). These contain information referring to that sales quantity of goods being in the possession of the tax payer that can only be transported with a document authentically proving the goods' origin. Moreover, NTCA can oblige the consignee, the recipient, the consignor and the transporter of goods for a declaration. Furthermore, if risk factors justify - except livestock and fast decaying goods - NTCA may also apply authority lock on the means of transport in order to ensure the identification of the goods.

Detailed rules regarding the operation of EPRTCS included in Regulation No. 5/2015 (II. 27.) NGM of the Minister of National Economy (hereinafter "R.") on the operation of the Electronic Public Road Trade Control System.

The scope of R. covers product purchase or other imports from other member states of the European Union for domestic purposes within the Community transported by vehicles subject to road toll payment and done by public transportation; product sale from inland to other member states of the European Union or export with other purposes; furthermore, the sale of VAT taxable product as first taxable domestic sale if it is not for and end-user inland. Public road transportation - be that either transportation of own goods or goods' transit for another party - with a few exceptions can only be carried out with having EPRTCS number ${ }^{6}$ (in order to determine the EPRTCS number, tax payers shall make and electronic announcement at the tax authority).

In the announcement a lot of information needs to be brought to the attention of the tax authority, with which legislators aim at the smooth identification of products and subjects participating in the transportation, however, excessive administration is not incentive for tax payers. The most significant data to be announced are data of the consignor and the recipient, place and time of loading and unloading, registration number of the transporting vehicle, determination of products connected to the EPRTCS number, reason for public road transportation (product sale, purchase, etc.). In case of 
purchase and selling of the so called dangerous products (which I am going to mention later on) net price of goods also needs to be provided.

For tax payers included in the database and for tax payers free from public debt, R. makes it possible to make a simplified data content announcement compared to the above mentioned, ${ }^{7}$ if their annual income exceeded 50 billion HUF and their tax number has not been previously suspended by the tax authority, and if the goods in question is not dangerous.

In case of goods' purchase or import with other aims within the Community from a consignor's address found in another member state of the European Union to an inland recipient's address, the recipient is obliged to announce the data. From an inland consignor's address to a recipient in another member state of the European Union, involving freight road transport with the aim of selling or other aims, the consignor has to announce the data. In case of product selling with freight transportation service from an inland consignor's address to an inland recipient's address, announcement obligation is the obligation of the consignor. If non-dangerous products are transported or get transported by the consignee, the announcement obligation is the task of the consignee.

Of course, tax payers obliged to declare should also announce changes and modification at the tax authority. Based on their announcement, the tax authority sends the EPRTCS number valid only for 15 days to the announcer via the electronic page of EPRTCS.

As I have already mentioned it above, certain goods are exempt from the obligation of data submission. R. lists general and individual exemptions. Regarding general exemptions, we can mention subjective and objective ones. Hence, military, law enforcement, disaster control services, foreign armed forces, vehicles transporting humanitarian relief supplies and transportation connected to international treaties and reciprocity do not fall under the effect of the system.

As to objective exemptions, it has to be mentioned transportation of such goods that are ensured anyway, i.e. goods requiring permission or declaration or goods which are under customs control. Hence, we can include excise goods, waste, goods requiring metal trade permission, pills for human usage or postal deliveries here.

In order to unburden everyday goods transportation, smaller amount, non-dangerous goods are also free from the effect of EPRTCS. Non-dangerous goods if their common gross weight does not exceed 2500 kilograms and their common non-taxed value does not exceed 5 million HUF do not need to be declared when they are carried from the same consignor to the same recipient in the same vehicle subject to road toll payment in one transportation. Those dangerous goods are also exempted from the announcement obligation that are transported from the same consignor to the same recipient in the same vehicle subject to road toll payment in one transport if their total gross weight does not exceed 500 kilograms and their common non-taxed value does not exceed 1 million HUF.

However, the obligation of daily declaration may be an exaggerated burden on certain tax payers. Therefore, there is a possibility for an individual exemption as well, if the tax payer's production organization peculiarities justify this and the inland loading address as well as the inland offloading address' distance (recipient) is maximum 20 kilometers. 
Regarding the transportation and announcement of risky goods, R. determines different rules than the ones referring to general goods. The circle of dangerous goods is determined in the Regulation of the Ministry for National Economy (NGM) No 51/2014. (XII. 1.) on determining risky products related to the operation of the Electronic Public Road Trade Control System. Basically, we can determine risky goods as goods that are hard or impossible to individually identify as they are generally transported in bulks. This goes hand in hand with the possibility that tax payers may use the same cargo continuously, for instance for the certification of selling within the Community. Risky products can be risky food such as various types of meat, vegetables, greases, oils, sugars or other products such as building materials, lubricants, clothes, shoes.

As a basic rule, for the EPRTCS number of risky food, tax payers shall have a so called "FELIR" identification number registered at the Information System of the National Food Chain Safety Office, and in case of product purchase from the Community, the first Hungarian place of storage has to be announced as well. Moreover, tax payers shall also provide risk guarantee in case of every dangerous product. The amount of security has to reach $15 \%$ of the net value of risky products registered in EPRTCS.

The guarantee can be accomplished via a transaction to a separated deposit account, or can be undertaken by a financial institution, cash flow institution, investment corporation, through guarantee registered at the national tax and customs authority. If tax payers can be found in the tax authority's qualified database or are included in the database for taxpayers free of public debt and the tax number of whom has not been suspended, they do not have to give guarantee.

The new system could not be effective enough without sanctions adjusted to it. As a sanction regarding the omission of the obligatory announcement or having it done with fictional content, it is determined that in this case goods shall be deemed of unconfirmed origin, upon which a default penalty amounting up to $40 \%$ of the value of the unreported goods may be imposed and The National Tax and Customs Administration may seize the goods to the extent of the amount of the default penalty or affix an official seal on each piece.

However, the system was introduced in January 2015, the relevant ministry declared that they would not levy penalty until the $28^{\text {th }}$ of February for those breaking the rules, hence, we can say that the system has only been operating since the $1^{\text {st }}$ of March 2015. At the time of the publication only two months passed since the $1^{\text {st }}$ of March but some achievements of EPRTCS can already be seen. These are primarily connected to the exposure of food supply of unconfirmed origin which are mostly products arriving from abroad. In these cases, foreign transporters ignorance can also be the reason for the discovered disorders.

40, 000 clients have required 1,5 million EPRTCS number until the $20^{\text {th }}$ of March and this number was more than 113, 500 at the beginning of April. Within the frame of the effective guarantee provision, clients paid 1,026 billion HUF, which amount reached 2,134 billion HUF until the $7^{\text {th }}$ of April, furthermore, bank guarantee in the amount of 827,978 HUF was also paid by tax payers in the framework of their guarantee provision obligation. $^{8}$ 
Controlling also led to great achievements as within one month the budget grew by 1,5 billion HUF only because of the tax authority's public road controlling has been activated in the framework of the EPRTCS system. The tax authority controlled 7502 cargos of which 283 ended up in the confiscation of chattel because of irregularities. The estimated value of chattels was almost 1 billion HUF. Besides, more than 0,5 billion HUF tax debit was paid by tax payers in cash in 1303 cases?

However, not everyone was satisfied with the introduction of this system. Most of them disapprove administrative obligations, guarantee obligations and the competitive disadvantage caused by these. They believed that as a result of these, Hungarian tax payers have a serious disadvantage on the market compared to enterprises not coming within the scope of the system. ${ }^{10}$

\section{Expansion of Reverse VAT Taxation}

Reverse taxation is significant in the fight against tax fraud as with its assistance, the state can achieve that pre-levied tax is paid before its deduction, reclaim. In branches where subcontractors did not get the counter-value of selling or service done by them, reverse taxation can especially be important, as these subcontractors were obliged to pay the tax in these cases as well. However, reverse taxation levies this burden on the tax payer customer, sub-contractors do not need to finance the amount of tax. At the same time, reverse taxation is also advantageous for the treasury as the possibility that the client main contractor deducts VAT without the issuer of the invoice has paid it, was abolished.

Member states may not only broaden the scope of reverse taxation based on cases listed in the current VAT directive or based on derogation lasting for years but they may do so in frames of more flexible QRM that is, quick reaction mechanism procedure against VAT fraud. At the same time, this taxation method is not practical to be introduced widely as during this it is only the end user (as the last subject of production and purchase procedure) who pays tax into the central budget; the latter means significant risk for the state, with special regards to certain probable end user misuses.

Hungary has applied the partial reverse taxation of VAT since the $1^{\text {st }}$ of January 2006. At first, it was applied to constructing-assembling services, property businesses, waste trade and selling of pledges, then the scope was constantly widened from the $1^{\text {st }}$ of July 2012 until the summer of 2014 by certain grain and protein plants. Later, the Council of the European Union with regards to Council directive 2013/43/EU amending Directive 2006/112/EC on the common system of value added tax, as regards an optional and temporary application of the reverse charge mechanism in relation to supplies of certain goods and services susceptible to fraud made it possible for member states to apply reverse taxation in case of grains and oily seeds until the $31^{\text {st }}$ of December 2018.

In 2013, the Hungarian state had planned on introducing reverse taxation on pork as well but it was not allowed according to the European Committee's report of 19 March 2013. Furthermore, on the $17^{\text {th }}$ of December 2013 and repeatedly in April 2014, the Committee refused the Hungarian petition on introducing reverse taxation in sugar 
trade having various fictive businesses. Among others, this lack of success created basis ground for the introduction of the EPRTCS system.

Utilizing its possibility provided by the European Union, with Act XXXIII of 2014 on the modification of certain financial acts, the Hungarian state expanded reverse taxation on temporary employment, employment through school cooperatives, various metals, wastes, debris, recovered paper or cardboard, glass jars, glass waste, plastic waste, chips, used or new rags, ropes, used batteries, batteries, etc. the sale of property collateral, the sale of 100,000 HUF assets, the sale of greenhouse gas emission allowances, as well as on certain steel industry products from the $1^{\text {st }}$ of January 2015 until the $31^{\text {st }}$ of December 2018.

\section{Application of Lower Tax Rate}

A further tool against tax fraud could be if states terminated the trade interest of people committing tax fraud. One of its methods is the application of significantly lower VAT than the average. As I have previously mentioned, the average degree of VAT is $27 \%$ in Hungary, which is considered significantly high worldwide. On one hand, it provides high income for the state, on the other hand, it urges tax payers for misuses and frauds.

One type of misuse can be found in the avoidance of community and import goods' VAT, thus goods imported to Hungary can be sold $27 \%$ cheaper than goods sold regularly, decreasing competitiveness by that. The other form of fraud is connected to fictive VAT deductions and reclaims. It can be attractive for tax payers that this way they can get sources from the state via VAT reclaim after invoices with unrealistic content and especially with reclaims.

Realizing all these, there is a significant need from the Hungarian traders' part that legislators shall expand the circle of goods and services having the lowest, 5\% VAT. Therefore, medicines and other health products, services were supplemented by the circle of pork and half-pork, cattle, goat, sheep and their meat. They are going to further extend the scope of goods and services with 5\% VAT rate by pork meat, immobile possessions like flats to $150 \mathrm{~m}^{2}$, and family houses to $300 \mathrm{~m}^{2}$ from 2016, chicken meat, egg and milk from 2017, hence assisting Hungarian traders and because of the expected lower price, consumers, as well.

\section{Tax Traffipax}

One of the most recent and most interesting tax control methods applied by the Hungarian Tax Administration since the spring of 2017 is the so called "Tax Traffipax" (the term Traffipax is used in Hungary to describe traffic enforcement equipment, or in other words speedcams used by the police during roadside checks), during which the NTCA publicizes it's inspection sites on its website beforehand. In this manner, the taxpayers are able to follow the way of controls; they are able to prepare themselves for the inspection(s) as well. 
The first thought seems to suggest, that this prior publication undermines the effectiveness of control, but the results so far are showing quite the opposite. Firstly: despite the fact of prior knowledge about the inspection, in 20-40\% of the cases there were deficiencies found. Secondly (and more importantly): during the "tax traffipax", taxpayers almost always show up revenue growth during the announced period. For instance, during an inspection day on the $10^{\text {th }}$ of March in the Budapest Grand Bazaar (a large marketplace), the average turnover growth for a taxpayer was above $40 \%$ (!) compared to the previous year. In this way the amount of revenue hidden revenues can be deducted - which in connection with the on-line cash registers can provide useful statistical data about the proportion of avowed and hidden revenues.

\section{Conclusion}

The basic aim of the Hungarian fiscal and tax policy is to ensure that the public revenues are met accordingly and in this way the Hungarian regulation and the activities of the NTCA are also subordinate to this purpose. Based on the fact that the Hungarian system of taxes is quite complex, flexible (and therefore rather volatile from a taxpayer's point of view) it is quite probable, that new types of controls, or normative solutions will emerge in the upcoming years. In my short study, I tried to point out the practice of tax controls and inspections: how and with what means are taxpayers "engaged" more efficiently. 


\section{References}

1. Government resolution No. 1315/2013. (VI. 12.) amending Government resolution No. 1059/2013. (II. 13) specifying the installation schedule of the online enabled cash registers to be connected to the system of the National Tax and Customs Administration Office.

2. www.kormany.hu/hu/nemzetgazdasagi-miniszterium/hirek (accessed 6 April 2017).

3. See further László Pardavi, New Tools against VAT Fraud in Hungary, 113-124, in Vladimír Babčák, Anna Románová \& Ivana Vojníková (eds.), Tax Law vs. Tax Frauds and Tax Evasion II. (Košice, Pavol Jozef Safarik University, 2015).

4. VAT Act $89 \S, 98 \S$.

5. VAT ACT Chapter VII.

6. EPRTCS number identifies that product unit which is transported by the same vehicle from one consignor to one consignee on a given route. R. $15 \$$.

7. Only the data of the consignor and the consignee, and the registration number of the transporting vehicle shall be announced.

8. http://logisztika.com/a-nav-tajekoztaton-mutatta-be-az-ekaer-eredmenyeit/ (accessed 6 April 2017).

9. http://portfolio.hu/gazdasag/adozas/itt_a_kormany_csodafegyverenek_elso_eredmenye.212769.html (accessed 6 April 2017).

10. The German-Hungarian Chamber of Commerce and Industry was concerned that the system significantly risks the competitiveness of every affected Hungarian enterprise. "The system can lead to serious defaults in the already existing transportation and production procedures, it imposes huge administrative burden on enterprises and has significant data protection risk that may endanger trade competitiveness." http://nol. hu/gazdasag/a-kmara-szerint-kart-okoz-az-ekaer-1511393 (accessed 6 April 2017). 